УДК 665.622.4.

ИССЛЕДОВАНИЕ СПОСОБОВ ОБЕЗВОЖИВАНИЯ НЕФТИ КАЛИНИНГРАДСКОЙ ОБЛАСТИ

\title{
STUDY OF OIL DEHYDRATION METHODS \\ IN KALININGRAD REGION
}

\author{
Е.В. Грохотова, Н.М. Мухина, Г.М. Сидоров
}

Уфимский государственный нефтяной технический университет, г. Уфа, Российская Федерация

Ekaterina V. Grokhotova, Nadezhda M. Mukhina, Georgiy M. Sidorov Ufa State Petroleum Technological University, Ufa, Russian Federation e-mail: ketrin2306@yandex.ru

Аннотация. Квалифицированное использование нефти требует выбор оптимальных схем и технологий, позволяющих в максимальной степени оптимизировать ее переработку. Однако нефть, извлекаемая из скважин, содержит пластовую воду с растворенными солями, растворенные газы органического (от $\mathrm{CH}_{4}$ до $\left.\mathrm{C}_{4} \mathrm{H}_{10}\right)$ и неорганического $\left(\mathrm{H}_{2} \mathrm{~S}, \mathrm{CO}_{2}\right.$, меркаптаны) происхождения, механические примеси. В этой связи первым этапом оценки качественных характеристик исходной нефти является ее подготовка, осуществляемая непосредственно на промыслах, а затем на НПЗ.

В статье представлены результаты исследования процессов по обезвоживанию нефти Калининградской области. Приведены результаты экспериментов по подбору деэмульгаторов для обезвоживания нефти, обоснован выбор оптимальных деэмульгаторов, с использованием которых наработан представительный образец нефти с остаточным содержанием воды $0,1 \%$ масс. Показано, что наиболее эффективное разделение 
происходит при предварительном нагреве нефтяной эмульсии, т.к. при нагревании эмульсионной нефти понижается еe вязкость, пленка эмульгатора расширяется и разрушается, а капельки жидкости сливаются друг с другом. Для интенсификации гидромеханических процессов смешивания водонефтяной эмульсии при подготовке нефти предложен разработанный специалистами УГНТУ струйный гидравлический смеситель.

Abstract. The qualified use of oil requires optimal schemes and technologies that allow optimizing its processing to the maximum extent. However, the oil extracted from the wells contains produced water with dissolved salts, dissolved gases of organic (from $\mathrm{CH}_{4}$ to $\mathrm{C}_{4} \mathrm{H}_{10}$ ) and inorganic $\left(\mathrm{H}_{2} \mathrm{~S}, \mathrm{CO}_{2}\right.$, mercaptans) of origin, mechanical impurities.

In this regard, the first step in assessing the source oil quality characteristics is its preparation, carried out first in the fields and then at the refinery.

The article presents the study results on the oil dehydration in Kaliningrad region. The results of experiments on the demulsifiers selection for oil dehydration are presented, the choice of optimal ones is substantiated, using which a representative sample of oil with a residual water content of $0.1 \%$ by mass has been accumulated. It is shown that the most effective separation occurs when the oil emulsion is preheated, because when emulsion oil is heated, its viscosity decreases, the emulsifier film expands and collapses, and the liquid droplets merge with each other. To intensify the hydro-mechanical processes of mixing oil-water emulsions in the oil preparation, a jet-type hydraulic mixer developed by the USPTU specialists was proposed.

Ключевые слова: деэмульгаторы, нефтяная эмульсия, обезвоживание, отстаивание, центрифугирование, бутылочный тест, смеситель

Keywords: demulsifiers, oil emulsion, dehydration, sedimentation, centrifugation, bottle test, mixer 
В добываемой на промыслах нефти содержание воды меняется в широких пределах (от долей процента до 90 \% в старых скважинах). На промыслах проводят первичную подготовку нефти - ее термохимическое обезвоживание без разбавления пресной водой (при неизменной концентрации солей в воде). Содержание воды уменьшается с 5-50 \% масс. до 0,5-1,0 \% масс. В ряде случаев нефть вторично промывают чистой водой для удаления хлоридов и отстаивают в резервуарах установок подготовки нефти с применением деэмульгаторов. Нефть, поступающая на НПЗ, должна соответствовать требованиям ГОСТ Р 51858-2002 по содержанию воды - не более 1,0 \% масс. и хлористых солей - не более 900 мг/дм ${ }^{3}$ [1], содержание механических примесей не должно превышать $0,001 \%$ по массе $[2,3]$.

Необходимость сокращения затрат, упрощение технологического процесса подготовки нефти, снижение металлоемкости установок подготовки нефти и себестоимости обработки требуют применения более эффективных деэмульгаторов, обладающих высокой деэмульгирующей способностью при низкой цене.

Выбор наиболее эффективных деэмульгаторов производится на основании лабораторных исследований с учетом свойств сырья и уточняется при опытно-промышленных испытаниях на действующей технологии.

В данном исследовании были проведены эксперименты по обезвоживанию нефтяной эмульсии Калининградской области обводненностью $24 \%$ масс. в лабораторных условиях. Характеристики обезвоженной нефти представлены в таблице 1.

Таблица 1. Физико-химические свойства обезвоженной нефти

\begin{tabular}{|c|c|c|c|c|c|}
\hline $\begin{array}{c}\text { Плотность } \\
\text { при } 20^{\circ} \mathrm{C}, \\
\text { кг } \mathrm{M}^{3}\end{array}$ & $\begin{array}{c}\text { Вязкость } \\
\text { кинематическая } \\
\text { при } 20^{\circ} \mathrm{C}, \\
\text { мм }^{2} / \mathrm{c}\end{array}$ & $\begin{array}{c}\text { Содержание } \\
\text { серы, \% масс. }\end{array}$ & $\begin{array}{c}\text { Содержание } \\
\text { смол, \% масс. }\end{array}$ & $\begin{array}{c}\text { Содержание } \\
\text { асфальтенов, } \\
\% \text { масс. }\end{array}$ & $\begin{array}{c}\text { Содержание } \\
\text { парафинов, } \\
\% \text { масс. }\end{array}$ \\
\hline 887,8 & 72 & 0,2 & 19,7 & 2,0 & 6,0 \\
\hline
\end{tabular}


Использовался наиболее простой способ удаления воды из сырой нефти - химический способ при атмосферном давлении с применением деэмульгаторов. Наиболее быстрым способом сравнительной оценки деэмульгирующей активности химического реагента является широко распространенный метод - Бутылочный тест («BottleTest») [4].

В работе были применены следующие деэмульгаторы:

1) Деэмульгатор «Evabreak 23», производитель ООО «ЭВАКЕМ»;

2) Деэмульгатор «Азол 6003 марка С», производитель $\mathrm{OAO}$ «Котласский химический завод»;

3) Деэмульгатор «УноКем 40001 марка 4», производитель АО «Неохимпродукт»;

4) Деэмульгатор «ФЛЭК-Д-012М», производитель ООО «ФЛЭК»;

5) Деэмульгатор «Demulex», производитель ООО «Поволжье ХимСнаб».

Объем раствора деэмульгатора, дозируемого в навеску эмульсии, вычисляется по формуле:

$$
V_{\partial}=\frac{m \times\left(100-W_{\mathrm{cp}}\right) \times Q_{p}}{1000},(\text { (мКл) }
$$

где $m$ - навеска эмульсии, мл;

$W_{c p}-$ исходная средняя обводненность эмульсии, \%;

$Q_{p}$ - заданная дозировка деэмульгатора, г/т.

Объективная оценка деэмульгирующих свойств реагента предусматривает определение его активности как при низких, так и при высоких температурах. Температура эмульсии в трубопроводах и аппаратах промысловой системы сбора составляет в пределах $5-15{ }^{\circ} \mathrm{C}$, в аппаратах ступени предварительного обезвоживания на установке подготовки нефти (УПН) - в пределах $20-25{ }^{\circ} \mathrm{C}$, в аппаратах ступени глубокого обезвоживания температура составляет в пределах $50-60{ }^{\circ} \mathrm{C}$ [5].

Время отстаивания может быть принято равным от 1 до 5 ч в зависимости от устойчивости эмульсии и динамики отделения воды, но на 
основании многолетнего опыта можно утверждать, что существенными являются первые 2 ч. Обычно за это время достигается близкая к максимальной глубина обезвоживания, которую может обеспечить деэмульгатор при правильно подобранных расходе и температуре.

Перед началом эксперимента визуально убедились в том, что водонефтяная эмульсия стабильна (не наблюдается выделение воды при отстое). После чего водонефтяную эмульсию налили в три цилиндра в количестве 50 мл. В каждый цилиндр вводились дозированные количества деэмульгатора $(20$ г/т, 40 г/т, 60 г/т).

Пробы перемешали вручную, не менее 200 качаний для полного растворения деэмульгаторов. Пробирки с исследуемой эмульсией оставили на 2 ч, регистрируя количество выделившейся водной фазы каждые 30 мин, измеряя высоту водного слоя. Аналогично провели эксперимент для других четырех деэмульгаторов. В таблице 2 приведены результаты эксперимента.

Оценку эффективности деэмульгаторов осуществляли, сравнивая объемы воды, выделившейся после отстоя.

На основе проведенного анализа Бутылочного теста выявлено, что наиболее эффективные среди испытуемых деэмульгаторов - это деэмульгаторы под № 1 и № 5 - Evabreak (рисунок 1) и Demulex (рисунок 2).

В зависимости от обводненности нефтяной эмульсии регулируется дозировка от 40 до 200 г/т.

Для максимального обезвоживания эмульсии с содержанием воды не более 1 \% в лабораторных условиях необходимо обеспечить следующее:

- предварительный нагрев эмульсии с дозированным деэмульгатором до $40-60{ }^{\circ} \mathrm{C}$;

- интенсивное перемешивание в роторной мешалке в течение 0,5 ч при 750-1000 оборотах в минуту;

- отстаивание в делительной воронке. 
Если после отстаивания эмульсии содержание остаточной воды более 1 \% применяют:

- центрифугирование при 3900 оборотах в минуту (в лабораторной центрифуге) для концентрирования и укрупнения капель воды в нефти;

- промывание водой в количестве 5-6 \% на эмульсию с целью выделения остаточной воды с последующим перемешиванием и отстаиванием.

Таблица 2. Влияние количества деэмульгаторов на эффективность отделения воды при $20{ }^{\circ} \mathrm{C}$

\begin{tabular}{|c|c|c|c|c|c|}
\hline \multirow{2}{*}{ Реагент } & \multirow{2}{*}{ Расход реагента, г/т } & \multicolumn{4}{|c|}{ Количество выделившейся воды, \% об., за время, ч } \\
\hline & & 0,5 & 1 & 1,5 & 2 \\
\hline \multirow[t]{3}{*}{1} & 20 & 12,50 & 18,84 & 18,84 & 18,84 \\
\hline & 40 & 12,84 & 25,66 & 25,84 & 25,84 \\
\hline & 60 & 12,50 & 24,92 & 29,00 & 35,16 \\
\hline \multirow[t]{3}{*}{2} & 20 & 6,26 & 13,76 & 13,76 & 13,76 \\
\hline & 40 & 6,66 & 17,50 & 17,50 & 17,5 \\
\hline & 60 & 6,84 & 18,66 & 22,00 & 25,08 \\
\hline \multirow[t]{3}{*}{3} & 20 & 12,08 & 18,08 & 24,16 & 24,16 \\
\hline & 40 & 12,08 & 24,16 & 24,50 & 48,66 \\
\hline & 60 & 12,26 & 24,50 & 30,16 & 30,16 \\
\hline \multirow[t]{3}{*}{4} & 20 & 7,08 & 12,26 & 22,08 & 24,92 \\
\hline & 40 & 7,76 & 13,26 & 24,50 & 27,08 \\
\hline & 60 & 7,92 & 14,34 & 25,26 & 30,00 \\
\hline \multirow[t]{3}{*}{5} & 20 & 4,00 & 8,16 & 12,08 & 12,08 \\
\hline & 40 & 4,16 & 8,34 & 16,92 & 18,26 \\
\hline & 60 & 5,76 & 13,00 & 32,16 & 40,92 \\
\hline
\end{tabular}




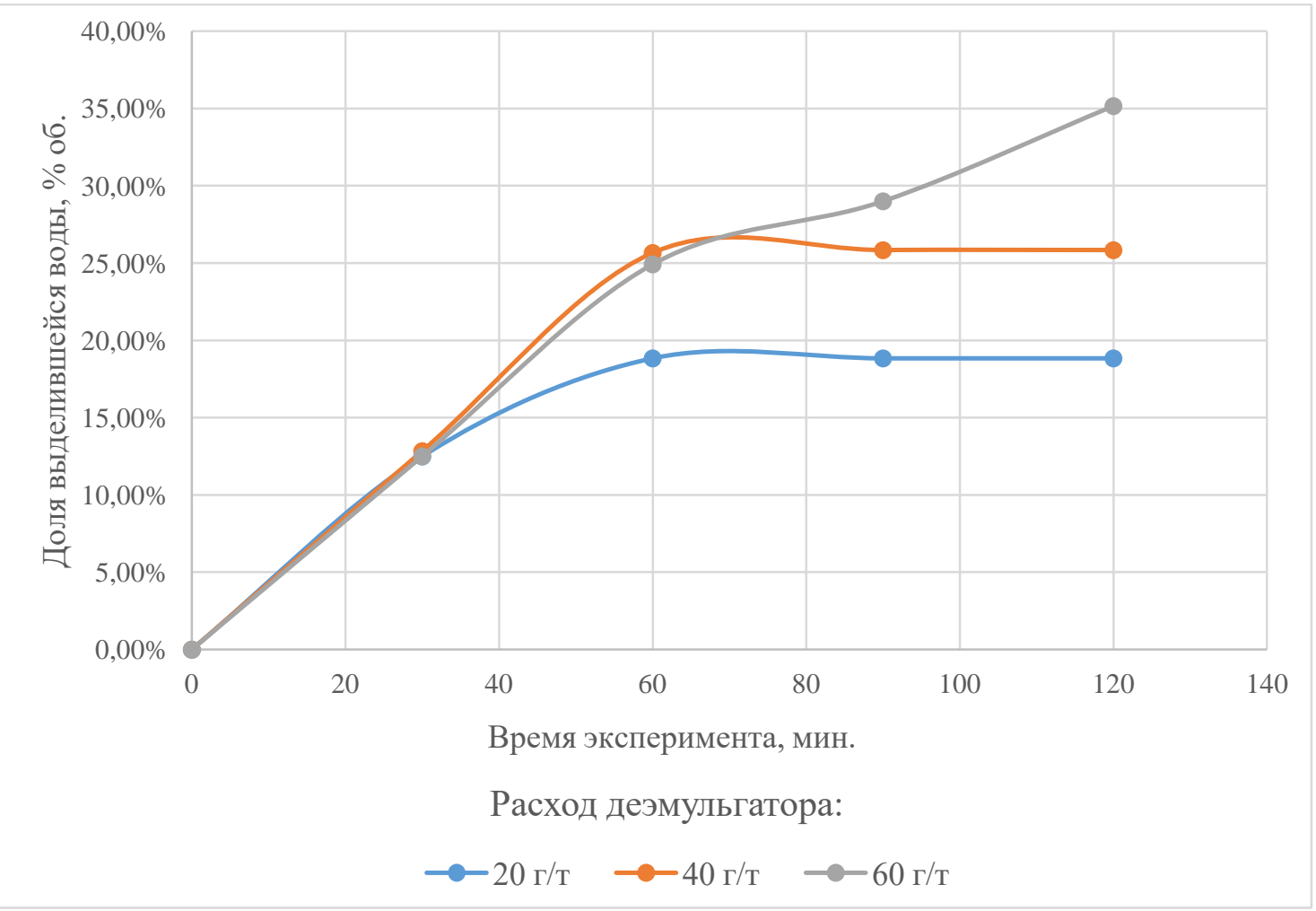

Рисунок 1. Эффективность деэмульгатора «Evabreak» при $20{ }^{\circ} \mathrm{C}$

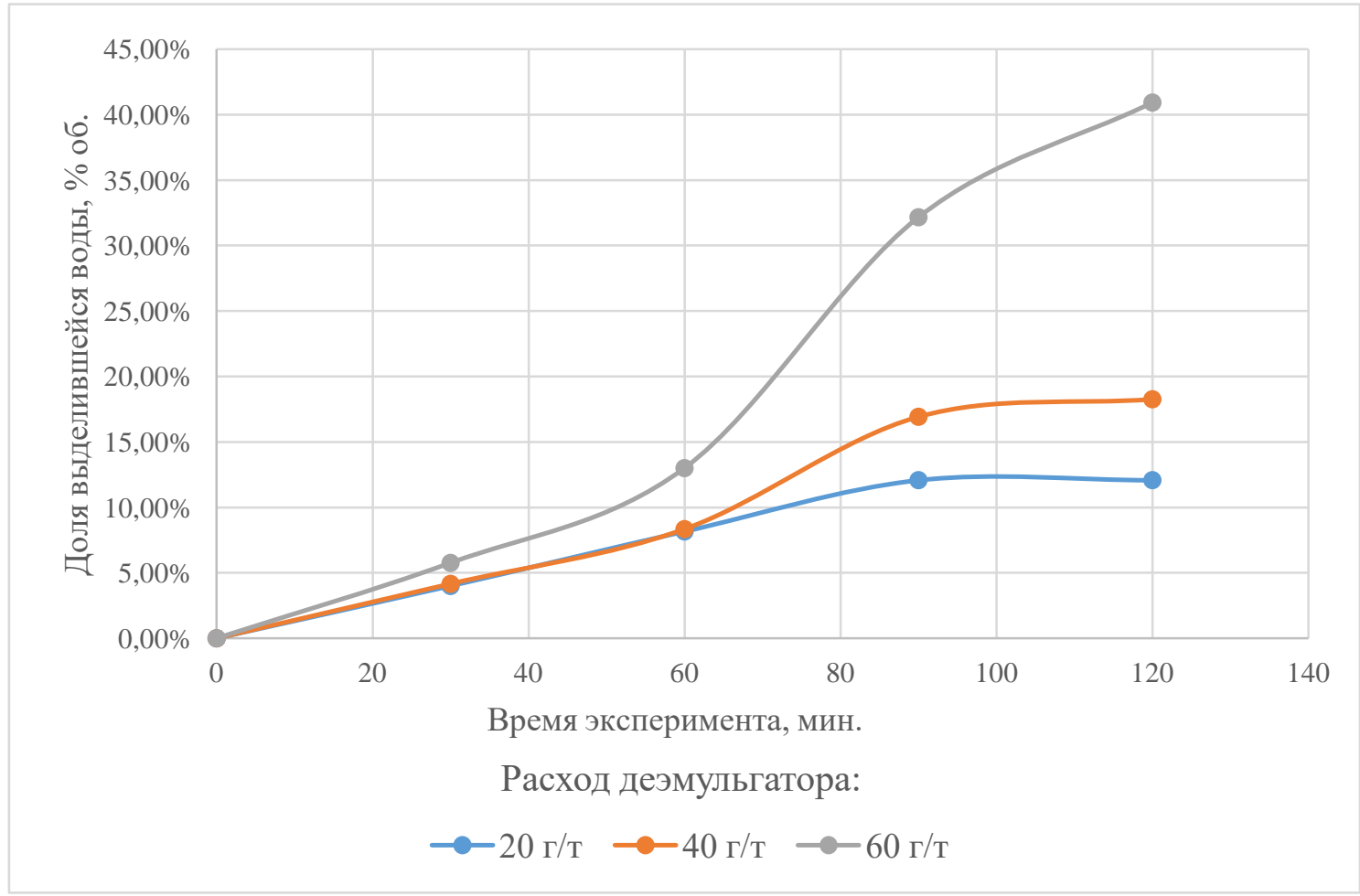

Рисунок 2. Эффективность деэмульгатора «Demulex» при $20^{\circ} \mathrm{C}$ 


\section{Первый эксперимент}

Было взято 2 пробы эмульсии по 450 мл. Дозировка деэмульгатора «Evabreak» составила в Іпробе - 50 г/т, во II - 100 г/т. Полученную смесь перемешали с помощью мешалки (30 мин при 750 оборотах в минуту) и перелили в делительные воронки соответствующего объема.

Оставляем нефтяную эмульсию отстаиваться на сутки (рисунок 3 ).

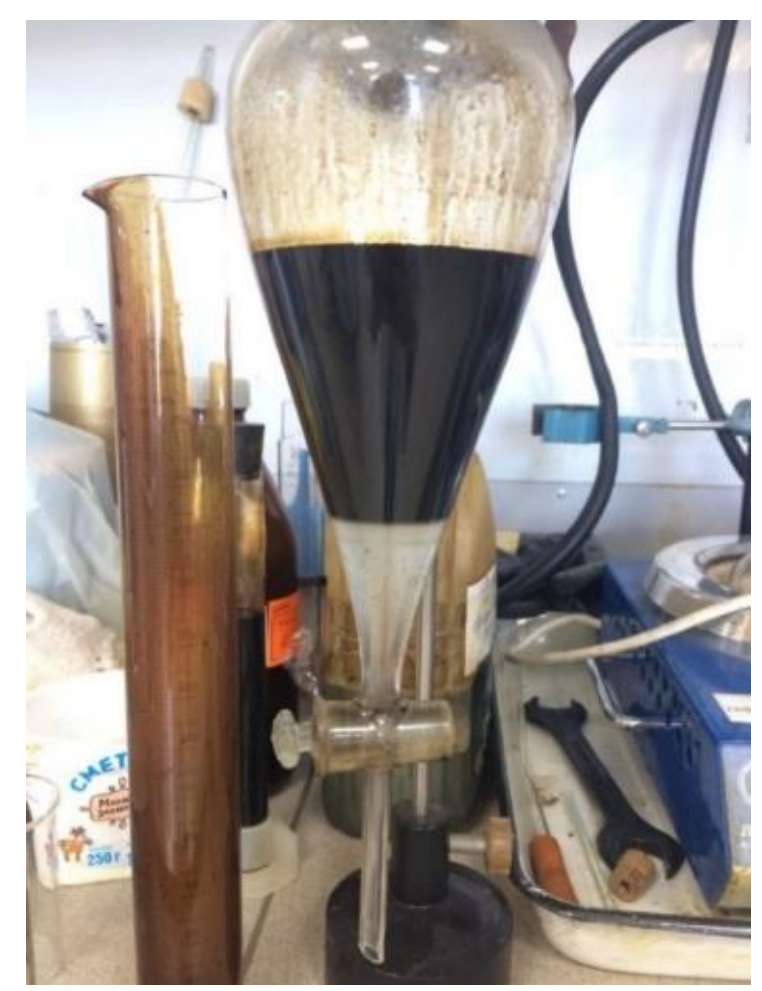

Рисунок 3. Нефтяная эмульсия с деэмульгатором через сутки отстаивания

Количество отстоявшейся воды через сутки:

- І проба - 60 мл (эффективность деэмульгатора - 55,56 \%);

- ІІ проба - 88 мл (эффективность деэмульгатора - 81,48 \%).

Отделенную нефть тщательно перемешиваем и отбираем пробу на анализ воды. Остаточное содержание воды определяем методом ДинаСтарка (ГОСТ 2477). Содержание воды в полученной нефти $-5,2$ \% масс.

Получение глубокообезвоженной нефти не всегда может быть достигнуто за счет деэмульгатора. Это достигается при дополнительном гидродинамическом воздействии. 
В лабораторных условиях в нашем эксперименте мы применим центрифугирование. Центрифуга представлена на рисунке 4.

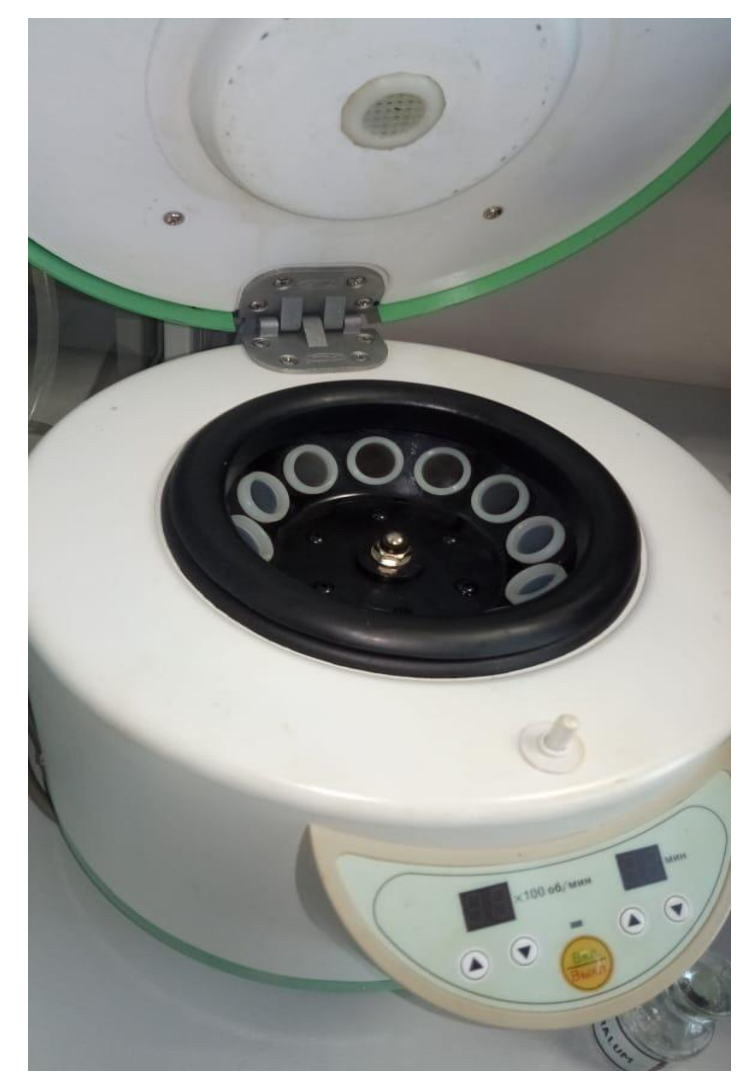

Рисунок 4. Лабораторная центрифуга

Способ деэмульсации центрифугированием основан на использовании эффекта различия плотностей дисперсной фазы и дисперсионной среды в сочетании с искусственно создаваемым центробежным полем. Поле создается в аппарате (центрифуге), где за счет больших скоростей вращения величина центробежного ускорения может быть во много раз больше ускорения свободного падения. При этом если плотность вещества дисперсной фазы больше плотности дисперсионной среды (что чаще всего имеет место в случае нефтяных эмульсий), то частицы дисперсной фазы будут отбрасываться к периферии центрифуги. Здесь водяные капельки дисперсной фазы эмульсии концентрируются, укрупняются и стекают вниз вдоль стенок центрифуги [6]. 
С помощью центрифуги в 2 пробах отделилось дополнительные 57 мл воды.

Отделенную нефть тщательно перемешиваем и отбираем пробу на анализ воды. Остаточное содержание воды - 0,1-0,2 \% масс.

\section{Второй эксперимент}

Одним из видов интенсификации разрушения эмульсий является повышение температуры подготовки нефти. При нагревании эмульсионной нефти понижается ее вязкость, пленка эмульгатора расширяется и разрушается, а капельки жидкости сливаются друг с другом. Однако при повышении температуры подготовки нефти происходит переход легких фракций нефти в газообразную фазу, что влечет за собой увеличение количества газа, повышение потерь нефти от уноса газом и снижение выхода товарной нефти.

Второй эксперимент аналогичен первому, отличие в том, что после добавления деэмульгатора был произведен предварительный нагрев водонефтяной эмульсии до $50{ }^{\circ} \mathrm{C}$.

После суток количество отстоявшейся воды (рисунок 5):

- I проба - 88 мл (эффективность деэмульгатора - 81,48 \%);

- II проба - 106 мл (эффективность деэмульгатора - 98,15 \%).

Отделенную нефть тщательно перемешиваем и отбираем пробу на анализ воды. Остаточное содержание воды - 1 \% масс.

Затем центрифугируем отстоявшуюся нефть. С помощью центрифуги в двух пробах отделилось дополнительные 12 мл воды. После чего остаточное содержание воды составило в нефти не более 0,1 \% масс.

Таким образом, в ходе лабораторных исследований по обезвоживанию нефтяной эмульсии с помощью деэмульгаторов получили нефть с содержанием воды не более 0,1 \% масс., что соответствует I группе по содержанию массовой доли воды в нефти согласно ГОСТ Р 51855-2002. 


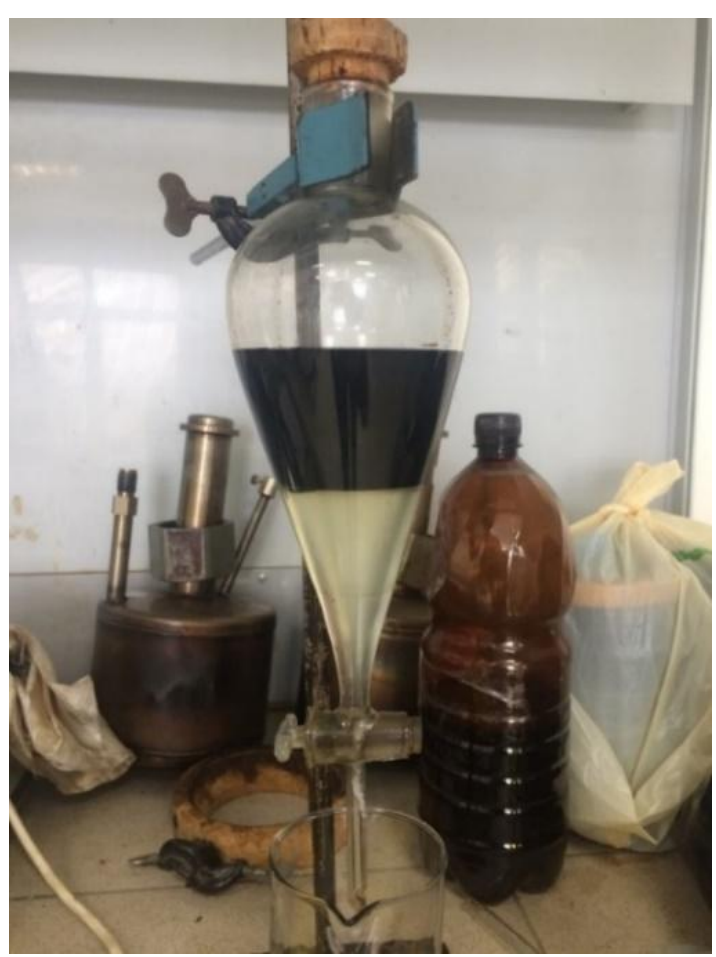

Рисунок 5. Нефтяная эмульсия с деэмульгатором через сутки отстаивания

Подготовка нефти на промыслах имеет важное значение для технологических процессов, связанных с добычей, сбором и транспортированием товарной нефти на НПЗ или на экспорт. В настоящее время в зависимости от характеристик нефти и условий добычи существует большое число разновидностей систем сбора и подготовки нефти с доведением ее до требований стандартов [7].

Исследуемая нефть имеет высокую температуру начала кипения и, как следствие высокую плотность, содержит до $20 \%$ воды и 165 мг/дм ${ }^{3}$ хлористых солей, по 40 ppm сероводорода и меркаптанов, что обусловливает необходимость проведения обезвоживания, обессоливания и очистки от сероорганических газов.

Одним из направления интенсификации гидромеханических процессов, осуществляемых в частности при смешивании водонефтяной эмульсии с деэмульгатором на первой ступени отстаивания, при смешении с пресной водой перед второй ступенью и при смешивании с поглотителем сероводорода в товарной емкости, широкое распространение получили струйные гидравлические смесители особой конструкции, где с целью 
повышения

эффективности

смешения

осуществляют

встречное

контактирование воды и нефти. Такие смесители позволяют проводить эффективное обессоливание нефти в промысловых условиях даже без подогрева пресной воды и нефти [8].

На рисунке 6 приведены струйный гидравлический смеситель и компьютерная модель схемы движения потоков.

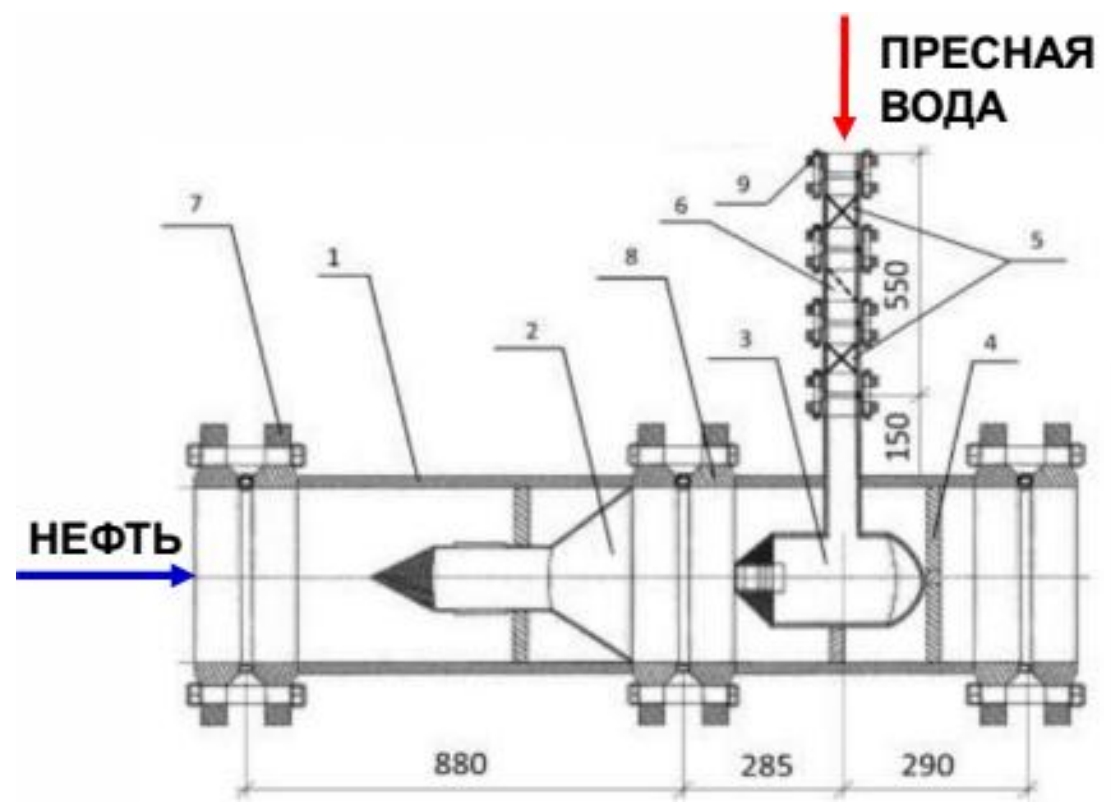

1 - корпус;

2 - завихритель нефти;

3 - завихритель воды;

4 -стабилизатор потока;

5 - кран шаровый Ду50;

6 - фильтр сетчатый Ду50;

7 - фланец крепежный Ду200;

8 - фланец сборочный Ду200;

9 - фланец крепежный Ду50;

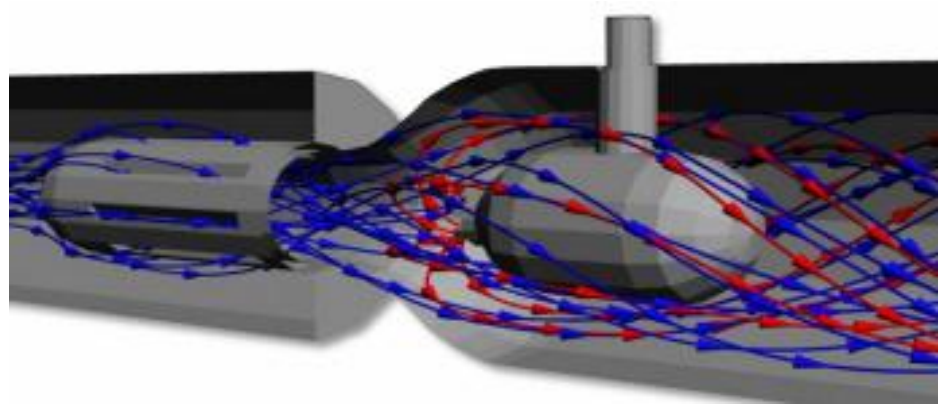

Рисунок 6. Струйный гидравлический смеситель и схема движения потоков нефти и воды в модели смесителя

Конструкция смесителя предусматривает дополнительную турбулизацию потока нефти в закручивающем устройстве. Струйный гидравлический смеситель показывает высокую эффективность работы в нестационарных режимных условиях. Он обеспечивает интенсивное 
перемешивание нефти с деэмульгатором и промывочной водой, эффективное обессоливание нефти.

Устройство работает следующим образом: нефть закручивается в закручивающем устройстве с тангенциальными соплами, закрученная струя расширяется в диффузоре и соударяется со струей пресной воды, подаваемой из распылительных сопел, расположенных соосно с закручивающим устройством. Встречное соударение закрученной струи нефти и струи пресной воды способствует хорошей диспергации воды в нефти [9].

К достоинствам этого типа насосов следует отнести простоту конструкции, и, как следствие, низкую стоимость изготовления, обслуживания и эксплуатации. Кроме того, их выгодно отличает высокая надежность в работе и небольшие габаритные размеры.

\section{Выводы}

Водонефтяные эмульсии являются весьма стойкими системами, и, как правило, под действием одной только силы тяжести не расслаиваются. Поэтому для ускорения процесса разрушения эмульсии еe наряду с отстоем одновременно подвергают и другим мерам воздействия, направленным на укрупнение капель воды, увеличение разности плотностей, снижение вязкости нефти. В проведенных экспериментах, описанные в статье, такими мерами являются: введение деэмульгатора и подогрев эмульсии. Показано, что наиболее эффективное разделение происходит при предварительном нагреве нефтяной эмульсии.

Представленные в работе методы по обезвоживанию нефти в лабораторных условиях могут применяться с целью подготовки проб обезвоженной нефти для дальнейших исследований ее физико-химических свойств: фракционного и углеводородного состава, плотности, содержания серы, анализа полученных из нефти фракций бензина, керосина, дизельного топлива, мазута и их практического применения. 


\section{Список используемых источников}

1. Баннов П.Г. Процессы переработки нефти. М.: ЦНИИТЭнефтехим, 2000. $224 \mathrm{c}$.

2. Рябов В.Г., Старкова Н.Н., Тархов Л.Г., Кудинов А.В. Переработка нефти и газа: учеб. пособие. Пермь: Изд-во Перм. гос. техн. ун-та, 2008. 103 с.

3. Хуторянский Ф.М., Галиев Р.Г., Капустин В.М. Глубокое обезвоживание и обессоливание нефти на НПЗ. Современный научнотехнический уровень процесса // Тез. докл. XVIII Менделеевского съезда по общей и прикладной химии. М., 2007. Т. 3. С. 461.

4. Сахабутдинов Р.З., Губайдулин Ф.Р., Хамидуллин Р.Ф. Методики испытаний деэмульгаторов для промысловой подготовки нефти: метод. указания. Казань: Казан. гос. технолог. ун-т, 2009. 35 с.

5. СТ-07.1-00-00-02 «Порядок проведения лабораторных и опытнопромысловых испытаний химических реагентов для применения в процессах добычи и подготовки нефти и газа» / ОАО АНК «Башнефть»; утв. 13.02.2013 № 53p. 2013. 83 с.

6. Виноградов В.М., Винокуров В.А. Образование, свойства и методы разрушения нефтяных эмульсий: метод. указания. М.: ФГУП «Нефть и газ», РГУ нефти и газа имени И.М. Губкина, 2007. 31 с.

7. Ахметов А.Ф., Копытина Е.В., Колобов А.Н. Свойства нефтей Талаканского месторождения и полученных нефтепродуктов // Башкирский химический журнал. 2007. № 4. Т. 14. С. 37-40.

8. Кашапова Л.А., Марушкин А.Б., Сидоров Г.М., Яхин Б.А. Опыт использования струйных гидравлических смесителей при подготовке нефти на промыслах Татарстана // Мир нефтепродуктов. Вестник нефтяных компаний. 2017. № 11. С. 37-39.

9. Сидоров Г.М., Яхин Б.А., Ахметов Р.Ф. Моделирование работы статического смесителя (нефть-вода) для обессоливания нефти и опытнопромышленное испытание // Успехи современного естествознания. 2017. № 2. C. 152-156. 


\section{References}

1. Bannov P.G. Protsessy pererabotki nefti [Oil Refining Processes]. Moscow, TsNIITEneftekhim, 2000. 224 p. [in Russian].

2. Ryabov V.G., Starkova N.N., Tarkhov L.G., Kudinov A.V. Pererabotka nefti i gaza: ucheb. posobie [Oil and Gas Processing: Tutorial]. Perm, Izd-vo Perm. gos. tekhn. un-ta, 2008. 103 p. [in Russian].

3. Khutoryanskii F.M., Galiev R.G., Kapustin V.M. Glubokoe obezvozhivanie i obessolivanie nefti na NPZ. Sovremennyi nauchnotekhnicheskii uroven' protsessa [Deep Dehydration and Desalting of Crude Oil at Refineries. Modern Scientific and Technical Level of the Process]. Tezisy dokladov XVIII Mendeleevskogo syezda po obshchei $i$ prikladnoi khimii [Proceedings of Reports of XVIII Mendeleev Congress on General and Applied Chemistry]. Moscow, 2007. Vol. 3, pp. 461. [in Russian].

4. Sakhabutdinov R.Z., Gubaidulin F.R., Khamidullin R.F. Metodiki ispytanii deemul'gatorov dlya promyslovoi podgotovki nefti: metod. ukazaniya [Test Methods for Demulsifying Agents for Oil Field Preparation: Method. Instructions]. Kazan, Kazan. gos. tekhnolog. un-t, 2009. 35 p. [in Russian].

5. ST-07.1-00-00-02 «Poryadok provedeniya laboratornykh $i$ opytnopromyslovykh ispytanii khimicheskikh reagentov dlya primeneniya $v$ protsessakh dobychi i podgotovki nefti i gaza», OAO ANK «Bashneft'»; utv. 13.02.2013 № 53r. [ST-07.1-00-00-02 «Procedure for Conducting Laboratory and Pilot Field Testing of Chemical Reagents for Use in Oil and Gas Production and Treatment Processes», ANK Bashneft; approved 02.13.2013 No. 53r.]. 2013. 83 p. [in Russian].

6. Vinogradov V.M., Vinokurov V.A. Obrazovanie, svoistva $i$ metody razrusheniya neftyanykh emul'sii: metod. ukazaniya [Formation, Properties and Methods of Destruction of Oil Emulsions: Method. Directions]. Moscow, FGUP «Neft' i gaz», RGU nefti i gaza imeni I.M. Gubkina, 2007. 31 p. [in Russian]. 
7. Akhmetov A.F., Kopytina E.V., Kolobov A.N. Svoistva nefti Talakanskogo mestorozhdeniya i poluchennykh nefteproduktov [Properties of Talakan Oils and Petroleum Products]. Bashkirskii khimicheskii zhurnal Bashkir Chemical Journal, 2007, No. 4, Vol. 14, pp. 37-40. [in Russian].

8. Kashapova L.A., Marushkin A.B., Sidorov G.M., Yakhin B.A. Opyt ispol'zovaniya struinykh gidravlicheskikh smesitelei pri podgotovke nefti na promyslakh Tatarstana [Experience of Using Jetting Hydraulic Mixer for Tretment Crude Oil in Tatarstan]. Mir nefteproduktov. Vestnik neftyanykh kompanii - World of Oil Products. The Oil Companies' Bulletin, 2017, No. 11, pp. 37-39. [in Russian].

9. Sidorov G.M., Yakhin B.A., Akhmetov R.F. Modelirovanie raboty staticheskogo smesitelya (neft'-voda) dlya obessolivaniya nefti i opytnopromyshlennoe ispytanie [Modeling Process of Static Mixers (Oil-Water) for Desalting Crude Oil and Pilot-Industrial Testing]. Uspekhi sovremennogo estestvoznaniya - Advances in Current Natural Sciences, 2017, No. 2, pp. 152-156. [in Russian].

\section{Сведения об авторах}

\section{About the authors}

Грохотова Екатерина Викторовна, канд. техн. наук, доцент кафедры «Технология нефти и газа», УГНТУ, г. Уфа, Российская Федерация

Ekaterina V. Grokhotova, Candidate of Engineering Sciences, Assistant Professor of Oil and Gas Processing Department, USPTU, Ufa, Russian Federation

e-mail: ketrin2306@yandex.ru 
Мухина Надежда Максимовна, магистрант кафедры «Технология нефти и газа», УГНТУ, г. Уфа, Российская Федерация

Nadezhda M. Mukhina, Undergraduate Student of Oil and Gas Processing Department, USPTU, Ufa, Russian Federation

e-mail:ms.naden@inbox.ru

Сидоров Георгий Маркелович, д-р техн. наук, профессор, профессор кафедры «Технология нефти и газа», УГНТУ, г. Уфа, Российская Федерация

Georgiy M. Sidorov, Doctor of Engineering Sciences, Professor, Professor of Oil and Gas Processing Department, USPTU, Ufa, Russian Federation e-mail: kaskad@ufanet.tu 